\title{
Kesalahan Profesional Dokter dan putusan Hakim: Dilema dalam Pelayanan Medis
}

\author{
Marcel Seran
}

DATA NASKAH

Masuk: 17 Juni 2014

Diterima: 21 September 2016

Terbit: 8 Desember 2016

KORESPONDEN PENULIS:

Fakultas Hukum Universitas Atma Jaya Makassar. Jl. Tanjung Alang No. 23

Makassar, Sulawesi Selatan.

E-mail:

marcelseran@yahoo.com

\section{ABSTRACT}

The relationship between doctor-patient in medical services is a unique. Distinctness of relationship between doctor-patient, is, beside, based on a legal relationship; it is also element of the trust becoming a base for the medical act of a medical doctor towards a patient. In it contains the aspect of the ethical and moral. For a medical action of a medical doctor to a patient is built on the basis of trust, however, if there is a dispute between doctor-patient in medical services, ideally court can not be an optional solution on the dispute. But what happened oftenly, the dispute settlement is done in the court. This creates some protests from the community of medical profession. They consider that law meddle too far the autonomy of the medical profession. To overcome this issue judicial profession could be a solution to settle the dispute by involving member of judges in medical profession. In that way, it eradicates the accusation of getting meddle too far to medical profession.

Keywords: Medical Malpractice, Judge’s Verdict, Medical Services.

\section{ABSTRAK}

Hubungan antara dokter-pasien dalam pelayanan medis merupakan suatu hubungan yang sifatnya unik. Keunikan dari hubungan dokter pasien ini, di samping didasarkan pada hubungan hukum, unsur kepercayaan menjadi landasan terciptanya upaya tindakan medis dokter pada pasien, sehingga terkandung aspek etis dan moral di dalamnya. Karena tindakan medis dokter pada pasien dibangun atas dasar hubungan saling percaya maka bila terjadi sengketa antara dokter - pasien dalam pelayanan medis, idealnya pengadilan bukan menjadi pilihan cara penyelesaian sengketa medis tersebut. Namun kenyataannya tidak demikian halnya, karena tidak jarang pangadilan menjadi pilihan penyelesaian terhadap sengketa medis antara dokter - pasien maka timbullah reaksi dari kalangan profesi medis. Mereka menilai hukum terlalu jauh mencampuri otonomi profesi medis.Untuk mengatasi 
problema ini maka ditawarkan solusi penyelesaian sengketa medis melalui peradilan profesi di mana hakim anggotanya dilibatkan profesi medis di dalamnya, sehingga tidak lagi dituding bahwa hakim pengadilan umum tidak memahami persoalan kedokteran. Dengan begitu carapenyelesaian sengketa medis dapat tercapai. Kata kunci: Kesalahan Profesional, Putusan Hakim, Pelayanan Medis.

\section{PENDAHULUAN}

Kesehatan mempunyai peran besar dalam meningkatkan derajat kehidupan manusia, oleh karenannya penyelenggaraan pelayanan medis harus dilaksanakan secara optimal dan hati-hati, karena jika tindakan medik tidak dilaksanakan secara optimal dan hati-hati akan menimbulkan kerugian pada pihak pasien. Kerugian yang diderita pasien dapat berupa kerugian materiil, fisik seperti cacat dan bahkan sampai pada kematian. Atas kerugian yang timbul dari hubungan dokter-pasien ini maka dokter dikatakan telah melakukan malpraktek/kesalahan professional (medical malpractice). Tuduhan kepada dokter yang telah melakukan kesalahan professional ini bila tidak ditangani secara bijak dan baik akan menimbulkan konflik kepentingan antara pasien -dokter. Sudikno Mertokusumo (1988:1) menyatakan bahwa konflik kepentingan adalah suatu tuntutan perorangan atau kelompok orang yang diharapakan untuk dipenuhi. Konflik kepentingan antara dokter-pasien ini jika tidak diselesaikan secara bijak dan baik antara keduanya maka konflik kepentingan ini akanberpotensi menjadi persoalan hukum yang pada gilirannya dapat diselesaikan melalui pengadilan.

Vonis hukumanpenjara 10 bulan yang dijatuhkan hakim kasasi kepada dokter Dewa Ayu Sosiary Prawani, dokter Hendy Siagian dan dokter Henry Simanjuntak atas meninggalnya Julia Fransiska Maketey di Rumah Sakit R.D Kandow Malalayang, Manado Sulawesi Utara, pada 10 April 2010 (Tempo Com, 27 November 2013) membuktikan bahwapenyelesaian sengketamedis melalui pengadilan ataskesalahan profesional dokter dalam pelayanan medis menjadi pilihan.

Putusan hakim kepada dokter Dewa Ayu Sosiary Pratiwi, dkk, tersebut ditetapkan dalam sidang hakim kasasi tanggal
18 September 2012 (Tempo Com, 27 November 2013). Ternyata putusan hakim kasasi ini mendapat sorotan dan tanggapan beragam dari berbagai kalangan di tengah masyarakat. Pro dan kontra-pun bermunculan baik dari kalangan profesi medis sendiri, profesi hukum, dan tak ketinggalan masyarakat umum. Kontra terhadap putusan hakim (umumnya dari kalangan profesi medis) berpendapat bahwa dokter Dewa Ayu Sosiary Pratiwi, dkk tidak melakukan kesalahan profesional karena sudah melakukan tindakan medis sesuai dengan standar profesi medis. Sedangkan pro putusan berpendapat bahwa putusan ini sudah tepat, karena dokter dipandang telah lalai melakukan tindakan medis sehingga menyebabkan meninggalnya pasien.Kasus kesalahan professional dari dokter Ayu Pratiwi dkk pada upaya hukum luar biasa (PK)dinyatakan bebas. Terlepas dari bebasnya dokter Ayu dari hukuman penjara, persoalan ini tetap menarik untuk dibahas, karena masih menyisahkan sejumlah persoalan yang berpotensi menjadi bahan perdebatan antara pro dan kontra atas kasus kesalahan profesional dokter yang timbul mana kala pengadilan menjadi pilihan penyelesaian. Hal-hal yang berpotensi menjadi bahan peselisihan terutama menyangkutq: lembaga mana yang nenentukan salah tidaknya seorang dokter melakukan kesalahan profesional dan cara penyelesaiannya dan lembaga mana yang berwenang untuk menangani kesalahan tersebut.

Konflik kepentingan yang timbul dari hubungan dokterpasien dalam pelayanan medis ini memang tergolong unik. Keunikan hubungan ini terletak pada adanya hubungan saling percaya. Pasien yang datang pada dokter senantiasa mempercayakan seluruh keadaan penyakit dan kesehatannya dan berbagai hal pribadi kepada dokter dan bila dirasakan bahwa dokter tidak sepenuhnya dapat memenuhi harapannya ia dapat beralih ke dokter lain. Dalam kondisi demikian, pasien dan keluarganya berada dalam ketidakmampuan untuk dapat menilai secara objektif, sejauh mana dokter telah menjalankan peran dan kewajiban sesuai dengan tuntutan ilmu pengetahuan kedokteran dan keahlian dalam memberikan pelayanan medis.

Dewasa ini permintaan pertolongan pasien kepada dokter untuk dilakukan pertolongan medis atau tindakan medis terhadap dirinya akan tercipta suatu hubungan antara subjek yakni hubungan antara dua subjek yang masing-masing 


\section{MEDIA
HUKUM}

mengemban kewajiban dan tanggung jawab yang satu terhadapyang lainnya (B. Arief Sidharta, 1988: 8). Hubungan antara dokter-pasien terwujud oleh dua unsur konstitutif yakni di satu pihak imbauan permintaan pertolongan karena kondisi kesehatannya dan di lain pihak kesediaan, serta kemungkinan untuk memenuhi imbauan tersebut berdasarkan keilmuan yang dimiliki.

Hubungan antara dokter - pasien semacam ini, pasien mengharapkan agar pengemban profesi medis secara bermartabat akan mengerahkan seluruh keahlian keilmuannya untuk melakukan tindakan-tindakan termasuk penggunaan teknologi dengan prasarananya yang tersedia sesuai dengan tuntutan berkeilmuan, kesaksamaan dan etika profesi yang perlu untuk mengamankan dan memulihkan integritasnya yang terganggu karena gangguan kesehatan (B. Arief Sidharta, 1988: 8).

Perkembangan pelayanan medis ternyata berbagai foktor turut mempengaruhi sehingga telah mengakibatkan hubungan antara dokter-pasien semakin tidak pribadi. Misalnya, semakin banyak pasien menunggu dan dokter mengejar waktu untuk berpraktek di tempat lain atau dengan semakin banyak peralatan diagnosis (penentuan jenis penyakit) dan terapeutik yang digunakan sehingga tidak lagi diperlukan penanganan langsung oleh dokter sendiri sehingga dokter sering lalai dan mempercayakan seluruhnya kepada peralatan medis tersebut.

Peralatan teknologi medis maju mampu meningkatkan mutu pelayanan kesehatan dan jangkauan siagnosis (penentuan jenis penyakit) dan terapi (penyembuhan) sampai kepada batasan yang tidak dibayangkan atau diduga sebelumnya. Namun peralatan teknologi maju (modern) ini tidak selalu mampu menyelesaikan problema seorang penderitan, bahkan ada kalanya menimbulkan efek sampingan bagi pasien seperti misalnya cacat, bahkan sampai mengakibatkan kematian.

Perlu disadari pula bahwa ilmu kedokteran bukanlah ilmu pasti sebagaimana halnya matematika. Membuat diagnosis (penentuan jenis penyakit) misalnya merupakan suatu seni tersendiri karena memerlukan imajinasi serta mendengarkan keluhan-keluhan yang disampaikan pasien dan memerlukan pengamatan yang seksama terhadapnya, sehingga belum pasti hasilnya (Veronica D. Komalawati, 1989: 13). Karena itu, jika upaya itu gagal dalam arti pasien tidak menjadi sembuh, cacat fisik atau bahkan meninggal hal ini merupakan risiko yang harus dipikul bersama baik oleh dokter maupun pasien.

Meskipun demikian, gugatan terhadap dokter atas kesalahan profesional dokter (Medical Malpractice) tetap saja dilakukan pasien. Gugatan terhadap dokter tetap dilakukan, karena pasien beranggapan bahwa dewasa ini seorang dokter dipandang sebagai orang yang mempunyai kemampuan keilmuan kedokteran yang senantiasa dapat mengatasi dan menyembuhkan setiap persoalan penyakit yang diderita pasien yang dihadapkan pada dokter. Oleh karena itu, mana kala terjadi kegagalan tidakan medis terhadap diri pasian maka kegagalan itu tidak lagi diterima sebagai suatu risiko tetapi kegagalan tersebut dipandang sebagai suatu kesalahan medis.

Penyelesaian sengketa medik antara dokter-pasien melalui jalur hukum menjadi masalah yang dilematis.Pilihan penyelesaian semacam ini kerap memperoleh reaksi dari kalangan profesi medis. Mereka berpendapat jika persoalan itu diselesaikan melalui jalur hukum maka otonomi profesi medis menjadi terancam dan bahkan dikatakan bahwa dunia hukum terlalu jauh mengintervensi profesi medis.Oleh karena itu, perlu diatur suatu cara/mekanisme penyelesaian yang bermartabat terhadap sengketa medis antara pasien-dokter, sehingga tidak lagi menjadi bahan perdebatan atau menjadi bahan tarik ulur antara dua kepentingan tersebut (dokterpasien).

\section{HUBUNGAN ANTARA DOKTER-PASIEN}

Pola hubungan antara dokter-pasien berawal dari pola hubungan vertikal yang bertolak dari prinsip father knows best dan melahirkan hubungan paternalistik antara sang pengobat dan penderita (Hermien Hadiati Koeswadji, 1998: 36). Dalam pola hubungan vertikal paternalistik ini posisi sang pengobat dan si penderita tidak sejajar. Posisi sang pengobat dipandang lebih tinggi derajatnya dari pasien, karena sang pengobat memiliki kemampuan keilmuan di bidang kedokteran. Karena itu pula sang pengobat dipandang mengetahui tentang segala sesuatu yang terkait dengan penyakit, sedangkan si penderita tidak tahu apa-apa tentang penyakit, apa lagi tentang bagaimana cara mengobatinya 
(cara penyembuhannya). Dalam hubungan paternalistik tersebut si sakit akan tergantung sepenuhnya dan menyerahkan seluruh nasibnya pada sang pengobat.

Praktik sehari-hari,dapat dilihat berbagai hal yang menyebabkan timbulnya hubungan antara dokter-pasien. Hubungan itu terjadi terutama karena beberapa sebab antara lain karena pasien sendiri yang mendatangi dokter untuk meminta pertolongan mengobati sakit yang dideritanya. Dalam keadaan seperti ini, pasien akan menyerahkan seluruh keadaan sakit ke pada sang pengobat (dokter) untuk menyembuhkan penyakitnya.Namun dalam perkembangannya hubungan antara dokter-pasien tidak lagi dilihat sebagai suatu hubungan kepercayaan semata, akan tetapi hubungan itu dilihat sebagai suatu hubungan hukum. Karena itu, menurut hukum, hubungan antara dokter-pasien merupakan suatu perjanjian yang dikenal sebagai transaksi terapeutik (penyembuhan) yakni perjanjian untuk melakukan tindakan medik yang mencakup diagnostik dan terapeutik.

Hubungan antara dokter-pasien sebagai suatu hubungan hukum maka sebelum dilakukan tindakan medis pada pasien, terlebih dahulu dokter harus memberikan informasi/ penjelasan kepada pasien dan pasien mengerti dan memahami penjelasan tersebut yang pada gilirannya pasien dapat memberikan persetujuan. Persetujuan itulah yang disebut dengan informed consent.

Informed consent pada prinsipnya merupakan suatu proses komunikasi antara dokter- pasien untuk menentukan terapi yang terbaik. Proses komunikasi tersebut diawali dengan dokter menyampaikan informasi atau penjelasan kepada pasien.Isi informasi/penjelasan yang dijelaskan sekurang-kurangnya memenuhi beberapa hal. Dalam Pasal 45 ayat (3) UU No. 29 Tahun 2004 tentang Praktik Kedokteran ditentukan bahwa isi informasi yang dijelaskan sekurang-kurangnya menyangkut: 1. Diagnosis dan tata cara tindakan medis, 2. Tujuan tindakan medis yang dilakukan, 3. Alternatif tindakan lain dan risikonya, 4. Risiko dan komplikasi yang mungkin terjadi, 5. Pragnosis terhadap tindakan yang dilakukan.

Berdasarkan penjelasan/informasi tersebut pada gilirannya pasien dapat menyampaikan kehendaknya yakni menyetujui atau menolak tindakan medis yang akan dilakukan. Karena itu, persetujuan pasien hanya mempunyai makna jika yang memberikan persetujuan memahami apa yang disetujui. Namun, karena pasien pada umumnya awam atau dalam keadaan tidak dapat menilai secara objektif maka seharusnya dokter berkewajiban untuk memberikan informasi/penjelasan, karena informasi/penjelasan kepada pasien merupakan suatu kewajiban. Dalam Peraturan Menteri Kesehatan RI No. 585/Men.Kes./Per/IX/1989 tentang Persetujuan Tindakan Medis menentukan bahwa: informasi tentang tindakan medik harus diberikan kepada pasien baik diminta maupun tidak diminta (Pasal 4 ayat (1)).Informasi/ penjelasan yang disampaikan seyogyanya informasi yang jelas, jujur dan lengkap yakni informasi yang adekuat tentang perlunya tindakan medis yang akan dilakukan dengan segala risikonya.

Idealnya bahwa isi informasi tersebut harus disampaikan secara jujur dan lengkap kepada pasien, baik diminta maupun tidak. Namun, sayangnya isi informasi yang ideal tersebut dalam praktik tidak sering ditemukan dalam pelayanan kesehatan. T. Sintak Gunawan (2006: 40) berpendapat bahwa umumnya dokter mudah membuat keputusan dan tidak memerlukan informasi dan data yang lengkap jika penyakit pasien jelas, ringan dan sederhana. Sedangkan untuk penyakit yang lebih berat dokter mungkin memerlukan beberapa pemeriksaan tambahan. Pemeriksaan tambahan penting agar keadaan penyakit pasien yang sebenarnya dapat segera dipastikan. Persoalannya, jika pasien dihadapkan pada suatu ketidakpastian maka tidak mudah bagi dokter untuk mengambil sikap yakni apakah akan memyampaikan informasi yang sejujurnya atau seberapa banyak informasi yang harus diungkapkan berkenaan dengan kondisi pasien tersebut.

Dilema etik semacam ini sebetulnya tidak perlu terjadi, bila dokter menyadari akan arti pentingnya informed consent dalam dunia kedokteran. Bahwa, Informed consent yang disampaikan secara baik, jujur dan lengkap justeru akan meningkatkan kepercayaan penderita (pasien) kepada dokter. Pasien percaya bahwa dokter akan sungguh-sungguh berupaya untuk menyembuhkan penyakit yang dideritanya, serta dapat pula mempererat hubungan antara dokter dan pasien(Gunawan (1991: 35) menyatakan bahwa jika informed consent dilaksanakan dengan cara yang baik maka akan: 1. Meningkatkan kemandirian seseorang, 2. Melin- 


\section{MEDIA
HUKUM}

dungi penderita, 3. Menghindari penipuan dan pemerasan, 4. Memacu sikap teliti pada pihak dokter, 5. Meningkatkan pengambilan keputusan yang rasional, 6. Meningkatkan keikutsertaan masyarakat.

Di Indonesia persetujuan pasien sebelum dilakukan tindakan medis merupakan keharusan (Pasal 45 ayat (1) Undang-Undang Nomor 29 Tahun 2004 selanjutnya disebut UU No. 29 Tahun 2004). Bahkan bila dokter yang melakukan tindakan medis tanpa persetujuan pasien atau keluarganya dapat dikenakan sanksi administratif berupa pencabutan surat ijin (Pasal 13 Peraturan Menteri Kesehatan RI No. 585/ Men.Kes/Per/IX/1989 tentang Persetujuan Tindakan Medis). Persetujuan diberikan baik tertulis maupun lisan (Pasal 45 ayat (4) UU No. 29 Tahun 2004). Persetujuan yang diberikan secara tertulis bila tindakan medis yang akan dilakukan mengandung risiko tinggi (Pasal 45 ayat (5) UU No. 29 Tahun 2004). Namun demikian, dalam keadaan tertentu persetujuan tindakan medis tidak diperlukan dalam hal pasien tidak sadarkan diri atau pingsan, serta tidak didampingi oleh keluarga terdekat dan secara medis pasien dalam kedaan gawat dan atau darurat yang memerlukan tindakan medis segera untuk kepentingan pasien tidak diperlukan persetujuan dari siapapun (Pasal 11 Peraturan Menteri Kesehatan RI No. 585 Tahun 1989).

Selanjutnya,Sudikno Mertokusumo (1992: 7-8), menyatakan bahwa kriteria seorang pasien dikatakan dalam keadaan gawat dan darurat adalah jika pasien: 1. Dalam keadaan shok, 2. Terdapat pendarahan, 3. Patah tulang, 4. Dalam keadaan kesakitan.Dengan demikian informed consent yang dilakukan dengan cara yang baik akan memperlancar proses pemulihan dan penyembuhan tindakan medik. Di samping itu, tentu saja melindungi dokter dari kemungkinan tuntutan / gugatan pasien jika terjadi kegagalan dalam upaya penyembuhan. Karena dalam hal ini pasien sendiri berperan serta untuk menentukan dapat dilaksanakan upaya penyembuhan tersebut.Dengan dilakukan penjelasan dan penjelasan ini diterima dan dimengerti oleh pasien maka pasien dapat memberi persetujuan yang pada gilirannya dapat dilakukan tindakan medis.

Tindakan medis yang dilakukan dokter pada pasien merupakan suatu tindakan hukum maka sebagai suatu tindakan hukum harus didahului dengan suatu perjanjian yang dikenal dengan transaksi terapeutik. Dalam perjanjian ini prestasinya adalah untuk melakukan suatu jasa tertentu berupa pertolongan medik dari dokter dan suatu imbalan prestasi dari pasien. Perjanjian terapeutik ini pada dasarnya termasuk perjanjian yang menghasilkan perikatan iktiar.Sehubungan dengan itu, dokter berkewajiban melakukan upaya semaksimal mungkin dengan mengerahkan seluruh keilmuan secara saksama sesuai dengan standar dan prosedur yang berlaku berdasarkan tingkat perkembangan ilmu kedokteran.Sebagai suatu perikatan pada umumnya maka terhadap transaksi terapeutik, berlaku juga ketentuan-ketentuan umum hukum perikatan sebagaimana diatur dalam KUHPerdata buku III yakni hubungan hukum dalam bidang hukum harta kekayaan antara dua pihak yaitu dokter sebagai pemberi pelayanan medis di satu pihak dan pihak lainnya adalah pasien sebagai penerima pelayanan medis. Prestasi sebagai objek perikatan yang harus dilaksanakan dapat berupa; memberi sesuatu, berbuat sesuatu dan tidak berbuat sesuatu (Pasal 1234 KUHPerdata). Di samping itu, perikatan juga dapat timbul karena undang-undang (tidak berdasarkan perjanjian). Misalnya, jika terjadi perbuatan melawan hukum (Pasal 1365, 1366 dan Pasal 1367 KUHPerdata) atau tindakan pengurusan kepentingan orang lain tanpa persetujuan terlebih dahulu (Zaakwaarneming) (Pasal 1354 KUHPerdata).

Prestasi dari hubungan antara dokter-pasien termasuk dalam berbuat sesuatu maka perikatan yang timbul dari transaksi terapeutik tersebut dalam kepustakaan dikenal dengan istilah inspannings verbintenis yaitu suatu perikatan yang harus dilakukan dengan sikap cemat dan hati-hati serta usaha keras dalam mengupayakan kesembuhan pasien (met zorg en inspanning). Karena prestasinya berupa suatu upaya maka hasilnya jelas belum pasti.

Hubungan dokter - pasien dalam pelayanan medis merupakan suatu hubungan hukum. Sebagai suatu hubungan hukum maka untuk sahnya hubungan hukum tersebut harus dipenuhi empat syarat yang diatur dalam Pasal 1320 KUHPerdata yaitu 1.Kata sepakat, 2.Kecakapan, 3. Hal tertentu, 4.Sebab yang halal. Dengan memenuhi syaratsyarat itu maka hubungan hukum tersebut mengikat para pihak sebagaimana halnya Undang-Undang dan pada 
gilirannya menimbulkan hak dan kewajiban bagi para pihak yaitu hak dokter di satu pihak dan kewajiban pasien di pihak lain secara timbal balik, serta prestasi yang harus dilaksanakan oleh masig-masing pihak.

Adapun hak dan kewajiban yang timbul dari hubungan hukum antara dokter-pasien diataur dalam Pasal 50, 51, 52 dan Pasal 53 UU No. 29 Tahun 2004 tentang Praktik Kedokteran. Pada Pasal 50 dikatakan bahwa dokter atau dokter gigi dalam melaksanakan praktik kedokteran berhak: 1. Memperoleh perlindungan hukum sepanjang melaksanakan tugas sesuai dengan standar profesi dan standar prosedur operasional, 2. Memberikan pelayanan medis menurut standar profesi dan standar prosedur operasional, 3. Memperoleh informasi yang lengkap dan jujur dari pasien dan atau keluarganya, 4. Menerima imbalan jasa. Sedangkan dalam Pasal 51 dikatakan dokter atau dokter gigi dalam melaksanakan praktik kedokteran mempunyai kewajinan: 1. Memberikan pelayanan medis sesuai dengan standar profesi dan standar prosedur operasional serta kebutuhan medis pasien, 2. Merujuk pasien ke dokter atau dokter gigi lain yang mempunyai keahlian atau kemampuan yang lebih baik, apa bila tidak mampu melakukan suatu pemeriksaan atau pengobatan, 3. Merahasiakan segala sesuatu yang diketahui tentang pasien, bahkan juga setelah pasien itu meninggal dunia, 4. Melakukan pertolongan darurat atas dasar perikemanusiaan, kecuali bila ia yakin ada orang lain yang bertugas dan mampu melakukannya, 5. Menambah ilmu pengetahuan dan mengikuti perkembangan ilmu kedokteran atau kedokteran gigi

Selanjutnya, mengenai hak dan kewajiban pasien diatur dalam Pasal 52 dan 53 UU No. 29 Tahun 2004. Dalam Pasal 52 dikatakan bahwa pasien dalam menerima pelayanan pada praktik kedokteran mempunya hak: 1. Mendapat penjelasan secara lengkap tentang tindakan medis sebagaimana dimaksudkan dalam 45 ayat (3), 2. Meminta pendapat dokter atau dokter gigi lain, 3. Mendapatkan pelayanan sesuai dengan kebutuhan medis, 4. Menolak tindakan medis, 5. Mendapatkan isi rekam medis. Sedangkan dalam Pasal 53 dikatakan bahwa pasien dalam menerima pelayanan pada praktik kedokteran mempunyai kewajiban:1. Memberikan informasi yang lengkap dan jujur tentang masalah kesehatannya, 2. Mematuhi nasihat dan petunjuk dokter dan dokter gigi, 3. Mematuhi ketentuan yang berlaku di sarana pelayanan kesehatan, 4. Memberikan ilmabalan jasa atas pelayanan yang diterima

Di samping itu, masih dijumpai beberapa hak dokter yang berkaitan dengan ketentuan-ketentuan profesi, seperti hak untuk bekerja menurut standar profesi medis, hak menolak tindakan medis yang tidak dapat dipertanggungjawabkan secara profesional, hak untuk menolak suatu tindakan medis yang menurut suara hatinya tidak baik. Dari hak dan kewajiban yang dikemukan di atas dapat diketahui bahwa hubungan antara dokter dan pasien adalah suatu hubungan hukum.

\section{KESALAHAN PROFESIONAL DAN PUTUASAN HAKIM}

Istilah profesi dijelaskan sebagai pekerjaan yang didasarkan pada keahlian akan suatu disiplin ilmu, yang dapat diaplikasikan baik pada manusia maupun benda dan seni (art).

Sehubungan dengan itu, Barber berpendapat bahwa, profesi adalah pekerjaan pelayanan yang bercirikan: 1 . Memiliki ilmu pengetahuan yang sistematis, 2. Orientasi primer lebih cenderung untuk kepentingan umum dari pada kepentingan diri sendiri dan 3. Memiliki mekanisme kontrol terhadap tingkah laku melalui kode etik yang dibuat sendiri untuk mematuhi aturan dalam kode etik tersebut (Sofwan Dahlan, 1992: 1). Karena itu, jika seseorang dalam menjalankan pekerjaannya dapat dikategorikan sebagai profesional apabila pekerjaan yang dilakukan didasarkan pada keahlian tertentu dari suatu disiplin ilmu yang diperolehnya melalui pendidikan tinggi atau universitas. Dalam menjalankan tugasnya ia terikat pada suatu kode etik tertentu. Kode etik tersebut dibuat oleh suatu organisasi profesi sebagai alat untuk mengontrol praktik setiap anggota profesi.

Sama halnya juga dengan profesi medis. Para dokter yang akan melalukan profesi medis harus mengikuti suatu masa pendidikan yang cukup panjang. Dari hasil pendidikan itu, mereka memiliki suatu kualifikasi keilmuan dan keterampilan yang jauh melebihi orang awam. Dengan kualifikasi keilmuan dan keterampilan khusus yang dimiliki tersebut, para dokter dapat melakukan profesi medis. 


\section{MEDIA
HUKUM}

Sehungan dengan itu, Pasal 1 butir 11 UU No. 29 Tahun 2004 tentang Praktik Kedokteran dikatakan Profesi Kedokteran adalah:

Suatu pekerjaan kedokteran yang dilaksanakan berdasarkan suatu keilmuan, kompetensiyang diperoleh melalui pendidikan yang berjenjang dan kode etik yang bersifat melayani masyarakat.

Selanjutnya, para dokter dalam menjalankan profesi medis, para dokter terikat pada suatu kode etik tertentu, sebagai mekanisme kontrol terhadap tingkah lakunya.Kode etik yang mengontrol tingkah laku para dokter dalam melakukan profesi medis di Indonesia diatur dalam Keputusan Menteri Kesehatan RI No. 443/Men.Kes/Sk/X/1983 tentang Berlakunya Kode Etik Kedokteran Indonesia Bagi Para Dokter Di Indonesia.Dengan mekanisme kontrol yang diatur dalam peraturan menteri ini sebagai seorang profesional di bidang kedokteran, dapat melakukan upaya pelayanan medis. Upaya pelayanan medis yang dilakukan harus memenuhi suatu standar tertentu yang disebut dengan Standar Profesi Medis. Standar profesi medis menurut Leenen (Fred Ameln, 1992: 56), dijelaskan bahwa berbuat secara teiliti menurut ukuran medis, sebagai seorang dokter yang memiliki kemampuan rata-rata dibandingkan dengan dokter dari kategori keahlian yang sama dengan upaya yang sebanding dengan tujuan konkrit tindakan medis tersebut.Karena itu, seorang dokter dalam melakukan profesi medis harus memenuhi standar profesi medis tersebut. Sebab standar profesi medis merupakan suatu ukuran yang disyaratkan dan dipakai untuk menilai ada atau tidaknya kelalaian atau kesalahan pada tindakan atau non tindakan dari seorang dokter yang melakukan upaya pelayanan medis pada pasien. Oleh karena itu, jika seorang dokter dalam melakukan upaya pelayanan medis, tidak sesuai dengan standar profesi medis yang disyaratkan maka dokter tersebut dikatakan melakukan kesalahan profesional. Kesalahan profesional di dalam upaya pelayanan medis disebut Malpractice. Dengan demikian, kesalahan profesional (medical malpractice) adalah kesalahan dalam menjalankan profesi medis tidak sesuai dengan standar profesi medis atau tidak melakukan tindakan medis menurut ukuran tertentu yang didasarkan pada ilmu pengetahuan medis dan pengalaman yang rata-rata dimiliki seorang dokter menurut situasi dan kondisi di mana tindakan medis itu dilakukan (Marcel Seran, 2013: 97-98). Meskipun demikian, dalam kenyataan sehari-hari tidak mudah untuk membedakan kesalahan profesional dengan risiko medis. Hal ini mengingat hasil suatu pelayanan medis tidak hanya berdasarkan pada tindakan medis, namun juga dipengaruhi oleh faktor-faktor lain seperti kemungkinan adanya komplikasi, daya tahan tubuh yang tidak sama, kepatuhan pasien dalam mengikuti petunjuk dokter dan lingkungan.

Berkenaan dengan itu, untuk membuktikan adanya suatu kesalahan profesional (medical malpractice) harus memenuhi 3 unsur utama yaitu:pertama, terbukti terjadi pelanggaran standar pelayanan. Kedua, terbukti pasien mengalami kerugian atau kerusakan setelah mengalami perawatan (culpa lata). Ketiga, terbukti adanya hubungan sebab akibat antara pelaksanaan yang tidak sesuai dengan standar dan kerugian atau kerusakan yang dialami pasien (Paulus Januar, 26 Mei 2006).

Berdasarkan ukuran tersebut majelis hakim kasasi menyatakan dokter Ayu Sosiary Prawani, dokter Hendy Siagian dan dokter Henry Simanjuntak dinyatakan lalai dalam melakukan tindakan medis yang menyebabkan meninggalnya Julia Fransiska Maketey. Atas meninggalnya Julia Fransiska Maketey, dokter Ayu dkk. dinyatakanbersalah melakukan malpraktek.Untuk itu mereka divonis hukuman penjara 10 bulan. Adapun alasan majelis hakim menjatuhkan vonis penjara 10 bulan kepada dokter ayu dan kawan-kawan karena bebepa pertimbangan.

Berikut ini pertimbangan majelis hakim kasasi seperti yang tercantum dalam putusan yang dirumuskan dalam sidang 18 September 2012 (2012 (Tempo Com, 27 November 2013), yang menyatakan bahwa:

1. Julia dinyatakan dalam keadaan darurat pada pukul 18.30 Wita, padahal seharusnya dinyatakan darurat sejak ia masuk rumah sakit pada pagi hari.

2. Sebagian tindakan medis Ayu dan rekan-rekannya tidak dimasukkan ke rekam medis.

3. Ayu tidak mengetahui pemasangan infus dan jenis obat infus yang diberikan kepada korban.

4. Meski Ayu menugasi Hendy memberi tahu rencana tindakan kepada pasien dan keluarganya, Hendy tidak melakukannya. la malah menyerahkan lembar 
persetujuan tindakan yang telah ditandatangani Julia kepada Ayu, tapi ternyata tanda tangan di dalamnya palsu.

5. Tidak ada koordinasi yang baik dalam tim Ayu saat melakukan tindakan medis.

6. Tidak ada persiapan jika korban mendadak mengalami keadaan darurat.

Atas vonis 10 bulan penjara kepada dokter Ayu dkk, tersebut mendapat rekasi dan perdebatan dari berbagai kalangan. Berikut ini beberapa point penting yang menjadi bahan perdebatan soal ada atau tidanya kesalahan profesional dalam kasus dokter Ayu dkk. Setelah vonis tersebut (Tempo Com, 27 November 2013):

1. Penyebab kematian masuknya udara ke bilik kanan jantung. Ini karena saat pemberian obat atau infus karena komplikasi persalinan.

Menurut O.C. Kaligis, pengacara Ayu, putusan Mahkamah Agung tak berdasar. Dalam persidangan di pengadilan negeri, kata Kaligis, sudah dihadirkan saksi ahli kedokteran yang menyatakan Ayu dan dua rekannya tak melakukan kesalahan prosedural.Para saksi itu antara lain Reggy -Lefran, dokter kepala bagian jantung Rumah Sakit Profesor Kandou Malalayang; Murhady Saleh, dokter spesialis obygin Rumah Sakit Pusat Angkatan Darat Gatot Soebroto, Jakarta; dan dokter forensik Johanis.Dalam sidang itu, misalnya, dokter forensik Johanis menyatakan hasil visum et repertum emboli yang menyebabkan pasien meninggal bukan karena hasil operasi. Kasus itu, kata dia, jarang terjadi dan tidak dapat diantisipasi.Para ahli itu juga menyebutkan Ayu, Hendry, dan Hendy telah menjalani sidang Majelis Kehormatan Etik Kedokteran pada 24 Februari 2011. Hasil sidang menyatakan ketiganya telah melakukan operasi sesuai dengan prosedur.

3. Terdakwa tidak punya kompetensi operasi karena hanya residence atau mahasiswa dokter dokter spesialis dan tak punya surat izin praktek (SIP).

Ketua Persatuan Obstetri dan Ginekologi Indonesia (POGI) dr. Nurdadi, SPOG dalam wawancara dengan sebuah stasiun televisi mengatakan tidak benar mereka tidak memiliki kompetensi. "Mereka memiiki kompetensi.
Pendidikan kedokteran adalah pendidikan berjenjang. Bukan orang yang tak bisa operasi dibiarkan melakukan operasi," katanya.Soal surat izin praktek juga dibantah. Semua mahasiswa kedokteran spesialis yang berpraktek di rumah sakit memiliki izin. Kalau tidak, mana mungkin rumah sakit pendidikan seperti di RS Cipto Mangunkusumo mau mempekerjakan para dokter itu.

4. Terjadi pembiaran pasien selama delapan jam.

Menurut Januar, pengurus Ikatan Dokter Indonesia, saat menerima pasien Siska, Ayu telah memeriksa dan memperkirakan pasien tersebut bisa melahirkan secara normal. Namun, hingga pukul 18.00, ternyata hal itu tak terjadi."Sehingga diputuskan operasi," ujar Januar.Sesuai prosedur kedokteran saat air ketuban pecah, biasanya dokter akan menunggu pembukaan leher rahim lengkap sebelum bayi dilahirkan secara normal. Untuk mencapai pembukaan lengkap, pembukaan 10, butuh waktu yang berbeda-beda untuk tiap pasien. Bisa cepat bisa berjam-jam. Menunggu pembukaan lengkap itulah yang dilakukan dokter Ayu

Meskipun demikian, dalam kenyataan sehari-hari tidak mudah untuk membedakan kesalahan profesional dengan risiko medis. Hal ini mengingat hasil suatu pelayanan medis tidak hanya berdasarkan pada tindakan medis, namun juga dipengaruhi oleh faktor-faktor lain seperti kemungkinan adanya komplikasi, daya tahan tubuh yang tidak sama, kepatuhan pasien dalam mengikuti petunjuk dokter dan lingkungan. Oleh karena itu, bila seorang dokter sudah melakukan tindakan sebagaimana mestinya sesuai dengan etika dan standar pelayanan medis meski mengalami kegagalan dan bahkan kegagalan itu sampai pada meninggal dunia maka yang terjadi bukan kesalahan profesional melainkan merupakan risiko yang harus diterima pasien dan keluarganya.

\section{PERADILAN PROFESI}

Bila terjadi sengketa medis antara dokter- pasien karena adanya kesalahan profesional dokter maka haruskah kesalahan profesinal dokter itu dapat diselesaikan melalui jalur hukum (pengadilan)?Tentu. Karena secara juridis di Indonesia pengadilan mempunyai kewenangan untuk itu (Marcel Seran dan Anna Maria Wahyu Setyowati, 2010: 


\section{MEDIA
HUKUM}

29-31)

Pilihan pnyelesaian sengketa medis antara dokter-pasien melalui pengadilan tersebut ternyata menjadi sangat berharga. Karena cara penyelesaian melalui pengadilan tidak jarang memperoleh reaksi dan tantangan yang tidak sedikit, terutama dari kalangan profesi medis (dokter). Entah karena kecurigaan yang berlebihan dari kalangan dokter bahwa cara penyelesaian semacam itu (lewat pengadilan) yang ditempuh maka akan membawa dampak buruk atau negatif dan bahkan ancaman bagi profesi dokter.

Di samping itu, para dokter juga kerap alergi berurusan dengan hukum karena dinilai sebagai suatu intervensi terhadap kedaulatan (otonomi) profesi. Lebih jauh dari itu, kekhawatiran utama adalah profesi kedokteran akan kehilangan martabatnya mana kala profesi medis harus diatur oleh hukum. Karena itu, menurut kalangan profesi medis (dokter) bila terjadi kesalahan profesional maka sebaiknya kesalahan itu dapat diselesaikan melalui organisasi profesi yakni melalui Majelis Kehormatan Disiplin Kedokteran (MKDKI).

Sementara dari kalangan masyarakat (pasien) beranggapan bahwa bila sengketa medis diselesaikan melalui organisasi profesi maka timbul kekhawatiran bahwa organisasi profesi tidak independen, kerap membela anggota profesinya (korps) dan kalaupun dikenakan sanksi maka sanksinya hanyalah berupa sanksi administratif seperti: 1 . Pemberian peringatan tertulis, 2. Rekomendasi pencabutan surat tanda registrasi atau surat ijin praktik, 3. Kewajiban mengikuti pendidikan atau pelatihan di instansi pendidikan kedokteran (Pasal 69 ayat (3) UU No. 29 Tahun 2004 tentang Praktik Kedokteran). Sanksi demikian tentu tidak sepadan dengan perbuatan (kelalaian atau kesalahan) yang dilakukan.

Memperhatikan tarik tolak antara dokter di satu pihak dan masyarakat (pasien) di pihak lain dalam proses penyelesaian sengketa medis tersebut maka salah satu solusi yang ditawarkan adalah dapat dibentuk peradilan profesi kedokteran seperti halnya peradilan niaga dan HAM.

Pembentukan peradilan semacam itu merupakan suatu bentuk perluasan terhadap yurisdiksi peradilan. Perluasan yurisdiksi peradilan semacam itu disebabkan oleh beberapa hal:

1. Masyarakat menjadi semakin sadar akan hak-haknya yang dilindungi oleh hukum dan peraturan perundangan;

2. Hubungan antara kedokteran dengan hukum menjadi semakin kompleks yang mengakibatkan berbagai macam tuntutan ganti rugi atas kesalahan yang dilakukan dokter

3. Masyarakat semakin meningkatkan fungsi dan seterusnya yang mengidentifikasi kekurangan-kekurangan dalam bidang penyelesaian kesehatan (Hermien Hadiati Koeswadji, 1992:75).

Tawaran dibentuknya peradilan profesi kedokteran dalam bentuk peradilan profesitersebut untuk menjawab kesenjangan yang terjadi yakni di satu pihak sudah ada MKEK (Majelis Kehormatan Etik Kedokteran) tetapi lembaga ini dalam praktik independensinya diragukan masyarakat (publik), karena kerap lebih melindungi anggota profesinya (korps). Di lain pihak, peradilan umum yang selama ini menjadi ujung tombak penyelesaian sengketa medik ditentang oleh kalangan profesi medis. Mereka menilai bahwa peradilan umum tidak memiliki tenaga ahli di bidang kedokteran. Selain itu, dapat dipahami pula bahwa hubungan antara dokter-pasien tidak semata suatu hubungan hukum saja tetapi berawal dari hubungan kepercayaan maka tentu saja terkait aspek etis dan moral. Karena itu cara penyelesaian tidak hanya dilihat dari aspek hukum saja tetapi perlu dipertimbangkan aspek etis dan moralnya.

Di samping itu juga, ditawarkannya peradilan profesi ini, karena sengketa medis yang diselesaikan melalui lembaga peradilan, terkesan hukum tidak bekerja sebagaimana mestinya, karena salah satu komponen dalam sistem hukum tidak bekerja, mandeg. Bekerjanya hukum dengan baik jika tiga kompenan dalam sistem hukum saling mendukung.Suatu sistem hukum menurut Lawrence M. Friedmanterdiri dari tiga komponen yaitu Substansi Hukum (Legal Substance), Struktur Hukum (Legal Structure), dan Budaya Hukum (Legal Culture) (Esmi Warassih, 2011: 2728). Ketiga komponen hukum ini saling mendukung untuk bekerjanya hukum secara maksimal dan baik. Jika salah satu komponen hukum mandeg dan tidak mendukung komponen lainnya makahukum tidak bekerja dengan baik. Tidak bekerjanya hukum ini bila dikaitkan dengan pendapat Wiliam J. Cambless dan Robert B. Seidmanbahwa lembaga penerap hukum (legal struktur) dalam hal ini lembaga pengadilan 
tidak bekerja maksimal karena adanya pengaruh/tuntutan dari legal culture (budaya hukum) masyarakat yaitu berupa tekanan dari kekuatan-kekuatan sosial dan personal (Esmi Warassih, 2011: 9-10) yang ada. Dalam konteks kasus dokter Ayu di atas putusan bebas itu diambil tidak terlepas dari adanya tekanan dari luar yang berpengaruh pada putusan yaitu berupa demo dan mogok kerja dari kalangan profesimedis.

Berdasarkan pertimbangan di atas maka kehadiran peradilan profesi kedokteran menjadi hal yang urgen. Perdailan profesidi bidang kedokteran ini ditawarkan sebagai jalan keluar untuk mengatasi persoalan tarik tolak antara para pihak dalam penyelesaian sengketa medis.Bentuk peradilan profesisebagaimana halnya peradilan niaga dan HAM yang masuk dalam lingkup peradilan umum sehingga tidak berbenturan dengan UU Kekuasaan Kehakiman yang hanya mengenal empat kamar yaitu peradilan umum, agama, peradilan tata usaha negara dan militer. Dengan begitu sekiranya dapat mengakhiri polimik, benturan (konflik) kepentingan yang kerap timbul dalam proses penyelesaian sengketa medis antara dokter-pasien.

\section{PENUTUP}

Hubungan dokter-pasien yang dibangun atas dasar hubungan saling percaya dalam upaya penyembuhan tidak jarang menimbulkan konflik kepentingan antara dokterpasein. Konflik kepentingan ini bila tidak diselesaikan dengan baik maka tidak mustahil hukum akan menjadi pilihan dalam penyelesaian sengketa medis tersebut.

Sengketa medis yang diselesaikan melalui jalur hukum sebetulnya tidak perlu ada, karena landasan hubungan dokter- pasien berawal/dibangun atas dasar hubungan saling percaya maka idealnya peneyelesaian melalui pengadilan bukan menjadi pilihan bijak dalam penyelesaian sengketa medis tersebut. Namun kenyataannya tidak demikian halnya karena tidak jarang pangadilan menjadi pilihan penyelesaian sengketa medis antara dokter - pasien maka timbulah reaksi atau tantangan dari kalangan profesi medis. Mereka menilai hukum terlalu jauh mencampuri otonomi profesi medis.

Berkenaan dengan itu, untuk mengatasi problema di atas maka tawaran solusi penyelesaian sengketa medis adalah melalui pembentukan peradilan profesi di mana hakim anggotanya dilibatkan profesi medis di dalamnya, sehingga tidak lagi dituding bahwa hakim pengadilan umum tidak memahami persoalan kedokteran. Dengan begitu cara penyelsaian sengketa medis dapat tercapai.

\section{DAFTAR PUSTAKA}

\section{Bukudan Jurnal:}

Arief Sidharta, B., Aspek Yuridis Hubungan Rumah Sakit, Dokter dan Pasien, Pro Justitia XVI, No. 2 April 1988.

Esmi Warassih, Pranata Hukum Sebuah Telaah Sosiologis, Badan Penerbit Undip, Semarang, 2011.

Fred Ameln, Kapita Selekta Hukum Kedokteran, Grafikatama Jaya, 1991.

Fred Ameln, Tanggung Jawab Rumah Sakit dan Tenaga Medis, Jakarta, 1992

Gunawa, Memahami Etika Kedokteran, Penerbit kanisius, Yogyakarta, 1991.

Hermien Hadiati Koeswadji, Beberapa Permasalahan Hukum dan Medik, Penerbit PT Citra Aditya Bakti, Bandung, 1992.

_- Hukum Kedokteran (Studi Tentang hubungan Hukum Dalam Mana Dokter Sebagai Salah Satu Pihak) Penerbit PT Citra Aditya Bakti, Bandung, 1998.

Kartono Muhamad dan T. Mulya lubis, Harian Kompas, 27 Januari 1987.

Marcel Seran, Kesalahan Profesional Dokter dan Tanggung Gugat Rumah Sakit, Penerbit Pustaka Magister, Semarang, 2013

Marcel Seran dan Anna Maria Wahyu Setyowati, Dilema Etika Dan Hukum Dalam Pelayanan Medis, Penerbit Cv. Mandar Maju, Bandung, 2010.

Paulus Januar, Mempersoalkan UU Mengenai malpraktek, Harian Kompas, 26 Mei 2006.

Sintak Gunawan, T.,Haruskah Dokter Mengatakan Yang Sebenarnya Kepada Pasien?, Respons, Jurnal Etika Sosial, Volume 11 Nomor 01 - Juli 2006.

Sudikno Mertikusumo, Mengenal Hukum Suatu Pengantar, Penerbit Liberty, Yogyakarta, 1988.

-_-_-_-_, Tinjauan Informed Consent dari segi Hukum, Seminar Obat dan Informed Consent, Komisi Pengabdian Masyarakat Fakultas Kedokteran UGM - YLK \& PERHUKI DIY, Yogyakarta, 1992.

Sofwan Dahlan, Perlindungan Dokter Dan Pasien Terhadap Kemungkinan Malpraktek, Aspek Hukum dan 
Pencegahan, Seminar dalam rangka memperingati 64 tahun Rumah Sakit Elisabeth, Semarang, 1992.

Veronica Komalawati, D., Hukum Dan Etika dalam Praktek Dokter, Pustaka Sinar Harapan, Jakarta, 1989.

\section{Website:}

Tempo Com, Jakarta, Malpraktek atau Tidak dr Ayu? Lihat Empat Poin Ini, diakses tanggal 27 November 2013/ 06.58

Tempo.Co, Jakarta, Inilah Alasan Hakim MA Menghukum dr Ayu, diakses, tanggal 27 November 2013/06.58 